\title{
Foreign investment and growth: A case of selected African economies
}

\section{Michael Appiah, Fanglin Li, Doreen Idan Frowne, Daniel Tetteh Donkor}

\section{A B S T R A C T}

Objective: The purpose of the study is to indicate how foreign investment impact on economic growth in some selected African economies.

Research Design \& Methods: The study employed the Panel ARDL (PMG) technique to estimate the impact of foreign investment proxy as FDI net inflows on Growth measured as GDP per capita.

Findings: The results of Panel ARDL indicate that foreign investment has a positive impact on economic growth as well as a positive sign of trade openness, inflation, and labor. The study stresses that for increasing economic growth there is a need to seek more foreign investments, increase trade openness and inflation at the same time improve upon employment conditions in selected African developing countries.

Contribution \& Value Added: The novelty of this research is in presenting and emphasizing the significance of FDI in some selected African countries on economic growth.

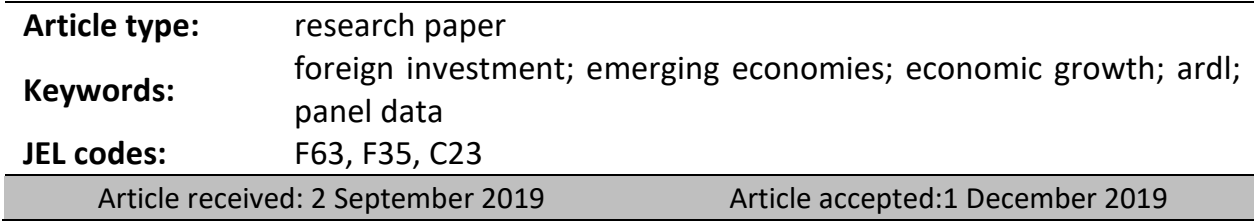

\section{Suggested citation:}

Appiah, M., Li, F., Frowne, D.I., \& Donkor, D.T. (2019). Foreign investment and growth: A case of selected African economies. International Entrepreneurship Review (previously published as International Entrepreneurship / Przedsiębiorczość Międzynarodowa), 5(3), 7-18. https://doi.org/10.15678/IER.2019.0503.01

\section{INTRODUCTION}

The influence of foreign investment $(\mathrm{FI})$ on growth is an area with enough investigations by many researchers around the world. Most of these researches center on developed countries whiles with fewer concerns on African nations. Foreign investment assumes a critical role in the improvement of the economy at large. The purpose of the study is to indicate how foreign investment impact on economic growth in some selected African economies. The study employed the Panel ARDL (PMG) technique to estimate the impact 
of foreign investment proxy as FDI net inflows. Growth measured as GDP per capita. Foreign Investment is explain to take overflow effects among all divisions within the economy of the host nation such as export of goods and service increment, importing advanced technology, implementing new advanced product developments, reducing the unemployment rate by the creation of employment and increasing the financial and funds of local investors. The overflow effects could be a lot higher in a specific business setting, for example, enhanced development stock, abnormal state of human development and financial sector development (Azman-Saini, Law, \& Ahmad, 2010; Herzer \& Klasen, 2008).

Foreign Investment inflows in Africa have been lower measuring it with that of other regions of the world, although in recent years there was increment it is still the lowest worldwide. Drawing more FDI inflows into the region demands improvement in the business setting such as human capital development and infrastructural development to have competitive returns from the Fl overflow effects (Gohou \& Soumaré, 2012; Yamin \& Sinkovics, 2009). The business atmosphere in African nations is insufficient, since the infrastructure, development stock, and human capital is low, making a comparison to other regions of the world. Recently, reports demonstrate $27 \%$ of African populace can access the internet, $22 \%$ of African populace are using mobile devices, transportation costs in Africa are the highest in the world and access to electrical power in Africa is of the lowest (OECD, 2015).

It is more significant to examine the entire effects of foreign investment on growth. Most studies are less focused in African countries (Almfraji, Almsafir, \& Yao, 2014; Sbia, Shahbaz, \& Hamdi, 2014). Studies of this nature in Africa are on the low. It has become necessary to bridge the distance within Africa by supporting policymakers in decision making as well as the introduction of an efficient policy in the growth situations. Economic growth and development can be influence by structural factors, such as foreign direct investment and trade openness; stability factors, such as inflation, and labor. The study examines the importance of these variables in affecting economic growth and development using yearly data from 1995 to 2015 and Panel ARDL methodology.

This study is organized in the following. Section 2 talks about the literature review and theory development, with Section 3 outlining the materials and methods used. Section 4 gives and discusses the findings, gives details about various checks whiles comparing the results with other studies. Finally, Section 5 deals with the conclusion.

\section{LITERATURE REVIEW AND THEORY DEVELOPMENT}

The hypothetical connection between foreign investment and growth mostly traced back to growth and dependency theories. Growth theories propose that foreign investment advances growth insisting that capital investment plays a role (Adams, 2009). The growth theories, however, stressed the transfer of technology through foreign investment. In light of the fact that developing nations need necessary infrastructure, for example, education, financial markets including political stability. (Adams, 2009; Bengoa \& Sanchez-Robles, 2003) separated from technology exchange, FDI additionally goes with its hierarchical and administrative abilities, marketing knowledge and market access through networks worldwide (Adams, 2009; Balasubramanyam, Salisu, \& Sapsford, 1996). Arslan, Tarba, and Larimo (2015) have contended that foreign investment plays a two-way work by adding up to capital requirements and expanding all-out total factor productivity. 
Interestingly, the dependency theories propose that over-reliance on foreign investment inflows is estimated to give negative effects on growth and income dissemination in light of the fact that FDI creates monopolies in the industrial sector, which in turn leads to underutilization of residential assets (Adams, 2009; Svilokos, Vojinić, \& Šuman Tolić, 2019). This infers foreigners control the economy and as opposed to growing naturally; it develops in a disarticulated manner (Browett, 1985). Thusly, the multiplier effect is feeble and prompts dormant growth in emerging nations (Adams, 2009).

Based on these theories, numerous exact investigations have been completed to look at the connection between FDI and economic growth, inter alia by (Borensztein, De Gregorio, \& Lee, 1998; Campos \& Kinoshita, 2002; Laura, Areendam, Sebnem, \& Sayek, 2004). For instance, Zhang (2001) detailed that foreign investment stimulates growth in nations where there are low levels of infrastructural development. Balasubramanyam et al. (1996) presumed that the upgrading impacts of FDI are more grounded in nations where the labor force is educated and encouraging the exportation instead of importation. Campos and Kinoshita (2002) stated that foreign investment in the form of technology transfer has a positive sign of growth. Likewise, Sokhanvar (2019) guarantee that small scale level of foreign investment can impact on growth and be treated without doubt, as the greater part in this study try not to control concurrences predisposition among nations.

A few investigations discover the insignificant nature of foreign investment in growth, for instance, Akinlo (2004) who finds out that there is no significance between FDI and growth in Nigeria. Again Ayanwale (2007) also confirms the insignificant nature of FDI on the growth of the Nigerian economy. Hermes and Lensink (2003) inferred foreign investment applies a critical adverse impact on the host nation. Comparative outcomes by Fry (1993) who find out that FDI does not exert any significant effects on growth. Finally, Sylwester (2005) talked about the insignificant position and relationship between FDI and economic growth.

Taking into consideration the direction of causality, Basu, Chakraborty, and Reagle (2003) contends that the evacuation of credit and liquidity problems had supported foreign investment in the Latin American nations. Nair-Reichert and Weinhold (2001) contend that the causality direction relies upon beneficiary nations. De Mello Jr (1997) contends that the impact of foreign investment on growth is exceedingly varied crosswise over nations has and these variations are increasingly articulated for mostly open economies. Hence, there is a requirement for the host nation on foreign investment inflows. 


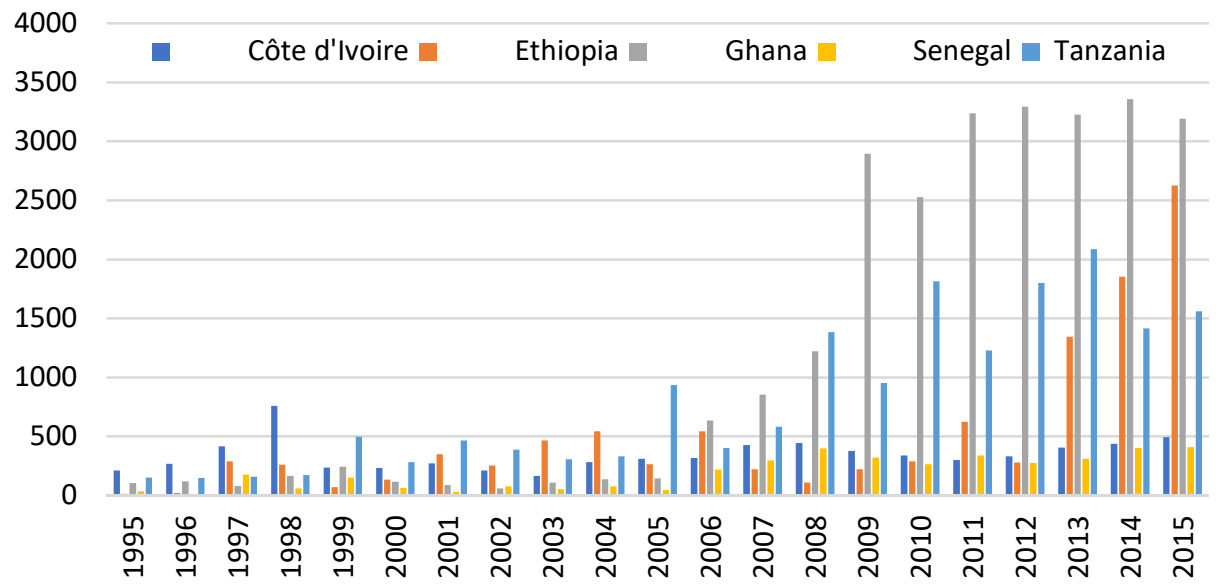

Figure 1. FDI inflows to study countries

Source: authors computations from WDI data base. (WDI, 2018).

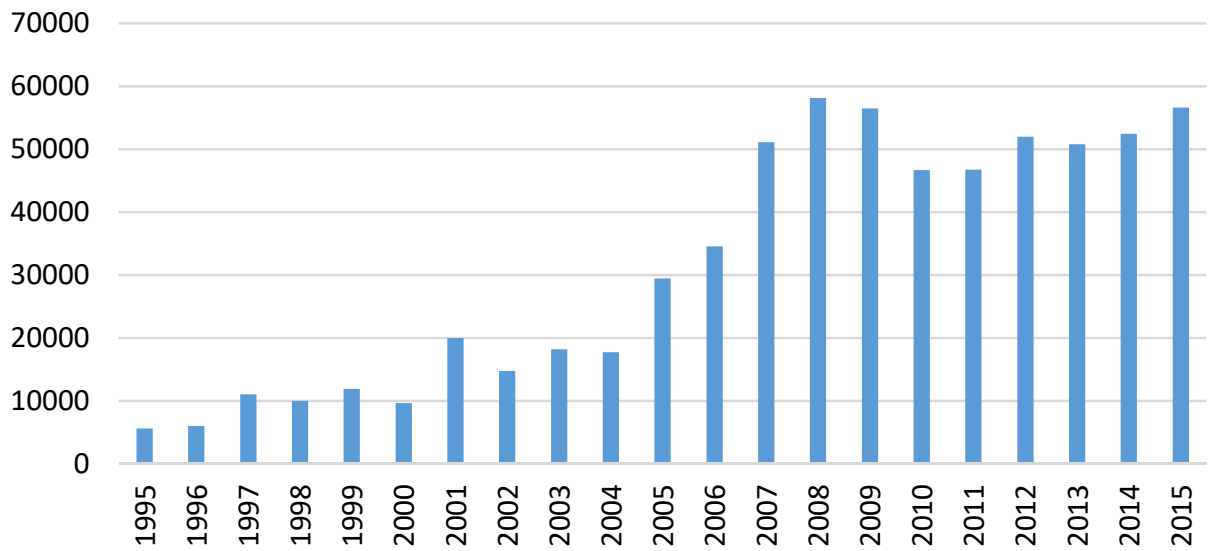

Figure 2. FDI inflows to Africa Billion USD

Source: authors computations from WDI data base. (WDI, 2018)

\section{MATERIAL AND METHODS}

A panel data for five African countries was engaged in this study, which is taking from the World Bank Development Indicators from the period 1995 to 2015. The selected countries for this investigation are Ghana, Ethiopia, Cote D'Voire, Senegal and Tanzania based on a report by www.africa.com stating them as the fastest growing economy in Africa. The variables used for this study will include GDPPC, which is Gross Domestic Product Per Capita as the dependent variable. Trade Openness (OPEN) as a proportion of export and import of gross domestic product per capita, FDI as foreign direct investment, Inflation which is proxies as the Consumer Price Index and LAB as total labor force all as explanatory variables. 
Table 1. Variable Description

\begin{tabular}{|c|c|c|}
\hline Variables & Unit/Proxy & Source \\
\hline $\begin{array}{c}\text { Gross Domestic Product } \\
\text { Per Capita (GDPPC) }\end{array}$ & Current USD & World Development Indicators \\
\hline Trade Openness (OPEN) & Current USD & World Development Indicators \\
\hline Foreign Direct Investment (FDI) & BOP Current USD & World Development Indicators \\
\hline Inflation (INF) & $\begin{array}{c}\text { Percentage/Consumer } \\
\text { Price Index }\end{array}$ & World Development Indicators \\
\hline Labor (LAB) & Thousand & World Development Indicators \\
\hline
\end{tabular}

Source: authors computations from WDI data base. (WDI, 2018).

\section{Empirical model}

Following the contribution of Solow (1956) in explaining growth theories, most writers identify growth-modelling variables for estimation. The accompanying variables utilized in this study include trade openness, labor, foreign direct investment, human capital, and exchange rate among others (Barro, 1995; Obadan, 2008). The growth model in this investigation is:

$$
\text { GDPPCit }=\alpha i t+\beta_{1} \text { OPENit }+\beta_{2} \text { FDIit }+\beta_{3} \text { INFit }+\beta_{4} L A B i t+\varepsilon t
$$

Where $G D P P C$ is the real GDP,OPEN is trade openness, $F D I$ is foreign direct investment, the $I N F$ is inflation and $L A B$ indicates total labor force, $\varepsilon t$ represents error term, $\beta_{1}-\beta_{4}$ are the factors to be assessed, $i$ speaks of the country whiles $t$ infers to a time period. Equation (1) states that the explanatory variables, which are trade openness (OPEN), foreign, direct investment $(F D I)$, inflation $(I N F)$ and total labor force $(L A B)$ influence $G D P$ Per Capita.

\section{Panel unit root test}

Levin, Lin, and Chu (LLC) approach to estimating unit root test was used in checking the stationarity of the variables. The lag selection criterion is according to the Schwarz information criterion (SIC). The unit root is estimated at both levels on a constant and at 1st difference constant.

\section{ARLD test for cointegration}

This study will employ ARDL estimation, which is a cointegration method by Pesaran and Shin (1996), to examine the lagged values. Theoretical and empirical research focuses on the long-run relationship within the economy. Pesaran and Shin (1996) studied the procedure of ARDL models for the estimation of long-term connections with variables integrated at I (0) order. The analysis becomes a little complex when the variables are at different-stationary or integrated of order 1 (I (1)). The cointegration procedure for this study is more about the examination of the long-run relationship between I (1) variables. Subsequently, a greater number of different estimates and hypotheses testing is dependent on this and precisely it is adopted for the investigation of I (1) variables (Pesaran \& Shin, 1996). Considering the study of Pesaran and Shin (1996), the ARDL (p;q) model will be used as the main equation:

$$
Y_{t}=\text { con }+\alpha_{1}+Y_{t-1}+\beta_{1} X_{t}+\beta_{2} X_{t-1}+\beta_{3} \pi+\beta_{4} \pi_{t-1}+\varepsilon_{t}
$$

Where $Y_{t}=\Delta Y_{t}+Y_{t-1}, X_{t}=\Delta X_{t}+X_{t-1}, \pi_{t}=\Delta \pi_{t}+\pi_{t-1}$ and $\varepsilon_{t}$ is error term, $X_{t-1}$, $X$ are the short run and the long-run coefficients of the model, respectively, and $\Delta$ is the 1st difference operator. $T(t)$ denotes time, the lag selection criterion is based on the 
AIC (Akaike Information Criterion) with $\mathrm{X}$ and $\mathrm{Y}$ as the vectors for the cointegration test. The long run and the short-run coefficient are estimated with much emphasis placed on the length, which talks about the main objective of the study, foreign investment and growth in emerging economies.

\section{Findings}

The variables for study are estimated for unit roots in level intercept and 1st Difference intercept as well. The lag selection criterion is according to the Schwarz information criterion SIC. Table 2 indicates the results unit root results. The findings from the test show that GDPPC, OPEN, INFLATION, and labor are stationary at a level signifying that these variables are I (0) with the exception of foreign direct investment. In addition, after estimating the test at 1st difference all the variables both the dependent and independent variables became non-stationary meaning the null hypothesis of unit root is rejected after the 1 st Difference estimation thus the variables are corrected at the order (1).

Table 2. Panel Unit Root Results

\begin{tabular}{|l|l|l|l|l|}
\hline \multicolumn{1}{|c|}{ UNIT ROOT } & \multicolumn{2}{c|}{ LEVEL INTERCEPT } & \multicolumn{1}{c|}{ 1ST DIFFERENCE INTERCEPT } \\
\hline \multicolumn{1}{|c|}{ VARIABLES } & \multicolumn{1}{c|}{ T. STATISTICS } & \multicolumn{1}{c|}{ PROB } & \multicolumn{1}{c|}{ T. STATISTICS } & \multicolumn{1}{c|}{ PROB } \\
\hline GDPPC & 2.31096 & 0.9896 & -3.41859 & $0.0003^{* * *}$ \\
\hline OPEN & 2.28593 & 0.9889 & -3.41375 & $0.0003^{* * *}$ \\
\hline FDI & -2.03737 & $0.0208^{* *}$ & -9.90427 & $0.0000^{* * *}$ \\
\hline INF & 5.01894 & 1.0000 & -0.61306 & 0.2699 \\
\hline LAB & 6.10720 & 1.0000 & -5.18347 & $0.0000^{* * *}$ \\
\hline
\end{tabular}

Note: 1 . Levin, Lin \& Chu t*. $\left({ }^{* *}\right),\left({ }^{* *}\right)$ and $\left({ }^{*}\right)$ indicate statistical significance at $1 \%, 5 \%$ and $10 \%$ respectively. Source: own study.

Table 3 gives the overall reports on the estimation results from equation 1 indicating the contribution of foreign direct investment on economic growth in Africa. GDPPC was used as a dependent variable in the equation with trade openness, foreign direct investment, inflation, and total labor force as the explanatory variables. Panel ARDL method was used to determine the long and short-run impact of the explanatory variables on the dependent variables, the selected ARDL model for this investigation is $\operatorname{ARDL}(1,1,1,1,1)$, with Akaike info criterion used as a lag selection criterion. The model estimated to come out with a Log-likelihood of 137.7832 and a standard deviation as 0.126701 .

In the long-run estimation, all the explanatory variables have a positive impact and contribution to the dependent variable. It is noted that there is a strong relationship between trade openness and economic growth with a coefficient of 1.097811 and a probability of 0.0000 indicating that trade openness is significant at a significant level of $1 \%$. (Appiah, Frowne, \& Frowne, 2019) evidence this in a study. Barro and Sala-i-Martin (1995) also confirmed that there is a positive relationship between trade openness and economic in his book. Again, it asserted the positive significant effects of trade openness on economic growth. Trade Openness stimulates the allocation of resources efficiently through relative advantage, allows the transfer of knowledge and technical progress, and promotes competitions in both international and domestic markets (Chang, Kaltani, \& Loayza, 2009). The results did not agree with a study by Durham (2004) who researched and failed to confirm a positive relationship between trade openness and growth. 
Table 3. ARDL Results (Selected Model: ARDL $(1,1,1,1,1)$ )

\begin{tabular}{|l|l|l|l|l|}
\hline \multicolumn{5}{|c|}{ LONG RUN RESULTS } \\
\hline Variable & Coefficient & Std. Error & t-Statistic & Prob.* $^{*}$ \\
\hline LOG (OPEN) & 1.097811 & 0.104336 & 10.52190 & $0.0000^{* *}$ \\
\hline LOG (FDI) & 0.101374 & 0.030687 & -3.303538 & $0.0015^{* * *}$ \\
\hline LOG (INF) & 0.367305 & 0.106134 & 3.460773 & $0.0009^{* * *}$ \\
\hline LOG (LAB) & -1.927860 & 0.344986 & -5.588234 & $0.0000^{* * *}$ \\
\hline \multicolumn{5}{|l|}{ SHORT RUN RESULTS } \\
\hline DLOG (OPEN) & 0.159927 & 0.120286 & 1.329562 & 0.1879 \\
\hline DLOG (FDI) & 0.030842 & 0.028587 & 1.078887 & 0.2843 \\
\hline DLOG (INF) & -0.005499 & 0.002444 & -2.249686 & $0.0276^{* *}$ \\
\hline DLOG (LAB) & -0.059486 & 0.560378 & -0.106154 & 0.9158 \\
\hline C & 3.888296 & 0.911158 & 4.267422 & 0.0001 \\
\hline \multicolumn{5}{|l|}{ MODEL FITNESS RESULTS } \\
\hline Mean dependent var 0.055289 & S.D. dependent var 0.126701 \\
\hline S.E. of regression 0.087778 & Akaike info criterion -1.976823 \\
\hline Sum squared resid 0.547052 & Schwarz criterion -1.117445 \\
\hline Log-likelihood 137.7832 & Hannan-Quinn criteria. -1.628586 \\
\hline
\end{tabular}

Note: $\left({ }^{* * *}\right),\left({ }^{* *}\right)$ and $\left({ }^{*}\right)$ indicate statistical significance at $1 \%, 5 \%$ and $10 \%$ respectively.

Source: own study.

From the results stated above, it's seen that in the long run there is a significant contribution of foreign direct investment on economic growth. Based on the prob value of 0.0015 stating it is significant at a level of $1 \%$, meaning when more and more of technology transfer and the use of modern equipment and machinery are employed in developing countries it results in increase in economic growth in Africa. This is proved by a study conducted by Borensztein et al. (1998) stating the positive significant contribution of foreign direct investment on economic growth. Again, Su and Liu (2016) proved that there is indeed a positive sign of foreign direct investment on economic growth in their study. Evidenced by Sunde (2017) in his study showed that there is a direct relationship between economic growth and foreign direct investment.

In Africa, a major determinant of macroeconomics has been inflation, since the rate of inflation is very high in most African countries. The results stated that, in the long-run inflation affects economic growth. It can be explained that a percentage increase will result in increase in economic growth. This means that inflation is a serious determinant of economic growth in Africa; cost of production is relatively high when there is high rate of inflation leading to low economic growth but a minimal or lower rate of inflation will intend increase economic growth as recorded in the results above. Barro and Sala-i-Martin (1995) who researched on inflation and economic growth, Jones and Manuelli (1995) evidenced this result to prove that inflation affects economic growth positively at the time he investigated about growth and the effects of inflation.

Labor force plays a very vital role in the economic growth of most African countries. In the results above, there is a positive sign of labor on economic growth, it is evidenced that labor is significant at a significant level of $1 \%$ stating that there was a significant effect of labor on economic growth in Africa from 1995 to 2015. This is proved by a study 
conducted by Khan (2007) who proved that the employment elasticity of GDP growth in emerging countries to be positive at the worldwide level, again Ajilore and Yinusa (2011) studied that total employment has grown between 0.3 and 0.38 for every $1 \%$ additional increase of GDP growth.

In the same vein, it can be noted in the above results that, none of the explanatory variables with the exception of inflation is a short-term measure and determinant for economic growth. All the variables are insignificant at all levels being it $10 \%, 5 \%$, and $1 \%$. For a quick measure of economic growth, inflation is a very important factor in the short run, thus the rate of inflation should be decreased to reduce the cost of production of goods and services.

\section{CONCLUSIONS}

The contributory role of foreign investment in growth in Africa in recent years has received much consideration by researchers and policymakers. Studies on this area available are not clear. In most recent studies, foreign direct investment has emerged as a determining the factor of economic growth. In light of this fact, the current study is an attempt to investigate the contributions of foreign investment on economic growth in developing economies of Africa. This study uses yearly panel data for the period 1995-2015 for 5 developing economies of Africa. The results of Panel ARDL (PMG) indicate that foreign investment has a positive impact on economic growth as well as a positive sign of trade openness, inflation, and labor. The study stresses that for increasing economic growth there is a need to seek more foreign investments, increase trade openness and inflation at the same time improve upon employment conditions in selected African developing countries.

Foreign investment helps in the growth and development of the economy. It is therefore recommended that as far as a foreign investment only does not improve the economy it also help to improve the standard of living for individuals of host countries. It is therefore appropriate for governments and administrations to set up policies to induce foreign investment inflow. Governments and administrations can introduce tax-free holidays for investors etc.

Again, improve human life can be a good source of growth of the economy as to governments providing social amenities like good roads, the provision of good and quality health care to individuals. The introduction of policies like health insurance, subsidization of tuition fees will help in the improvement and development of the human capital.

Most African countries are faced with the issue of inflation, governments and administrations can put up strategies to reduce the rate of inflation. Governments can encourage the patronage of locally produced goods and services to reduce the importations, which in turn will help reduce the rate of inflation.

There are some limiting factors hindering the study. This study only dealt with a few African countries and not all emerging countries on the African Continent. Again, there was a problem with data availability and that led to the limitation of data from 1995-2015. The selection of factors and variables differ from other research studies and became a limitation since there was no data available for such variables. Lack of funds for the purchase of data other than what is available from international organizations was another limiting factor. Finally, some recommendations are not applicable to some developing African countries because of different economic situations and climatic conditions.

We encourage further work in this range to better the findings. The data as it expanded back to 2015, anticipating utilize long time-series data. Maybe the study countries 
do not talk for the complete squib Saharan Africa region. At last, we consider the potential for foreign investment to have countrywide impacts, but macro provision may emerge at regional (i.e. Provincial levels) indeed, in the event that they are not countrywide. These limitations warrant proceeding study of this issue.

\section{REFERENCES}

Adams, S. (2009). Foreign direct investment, domestic investment, and economic growth in Sub-Saharan Africa. Journal of Policy Modeling, 31(6), 939-949. https://doi.org/10.1016/j.jpolmod.2009.03.003

Ajilore, T., \& Yinusa, O. (2011). An analysis of employment intensity of sectoral output growth in Botswana. Southern African Business Review, 15(2).

Akinlo, E. (2004). Foreign direct investment and growth in Nigeria: An empirical investigation. Journal of Policy Modeling, 26(5), 627-639. https://doi.org/10.1016/j.jpolmod.2004.04.011

Almfraji, M. A., Almsafir, M. K., \& Yao, L. (2014). Economic growth and foreign direct investment inflows: The case of Qatar. Procedia-Social Behavioral Sciences, 109, 1040-1045. https://doi.org/10.1016/j.sbspro.2013.12.586

Appiah, M., Frowne, D. I., \& Frowne, A. I. (2019). Corruption and Its Effects on Sustainable Economic Performance. International Journal of Business Policy \& Governance, 6(2), 12-24. http://dx.doi.org/10.19085/journal.sijbpg060201

Arslan, A., Tarba, S., \& Larimo, J. (2015). FDI entry strategies and the impacts of economic freedom distance: Evidence from Nordic FDIs in transitional periphery of CIS and SEE. International Business Review, 24(6), 997-1008. http://dx.doi.org/10.1016/ j.ibusrev.2015.03.004

Ayanwale, A.B. (2007). FDI and economic growth: Evidence from Nigeria. AERC Research Paper, 165. Retrieved from http://www. africaportal.org.

Azman-Saini, W.N.W., Law, S.H., \& Ahmad, A. H. (2010). FDI and economic growth: New evidence on the role of financial markets. Economics Letters, 107(2), 211-213. https://doi.org/10.1016/j.econlet.2010.01.027

Balasubramanyam, V.N., Salisu, M., \& Sapsford, D. (1996). Foreign direct investment and growth in EP and IS countries. The Economic Journal, 106(434), 92-105. https://doi.org/10.2307/2234933

Barro, R. J. (1995). Inflation and Economic Growth. NBER Working Paper, 5326. http://www.nber.org https://doi.org/10.3386/w5326

Barro, R., \& Sala-i-Martin, X. (1995). Economic growth, advanced series in economics. London: McGraw-Hill Press.

Basu, P., Chakraborty, C., \& Reagle, D. (2003). Liberalization, FDI, and growth in developing countries: A panel cointegration approach. Economic Inquiry, 41(3), 510-516. https://doi.org/10.1093/ei/cbg024

Bengoa, M., \& Sanchez-Robles, B. (2003). Foreign direct investment, economic freedom and growth: new evidence from Latin America. European Journal of Political Economy, 19(3), 529-545. https://doi.org/10.2139/ssrn.353940

Borensztein, E., De Gregorio, J., \& Lee, J.-W. (1998). How does foreign direct investment affect economic growth? Journal of International Economics, 45(1), 115-135. https://doi.org/10.1016/S0022-1996(97)00033-0

Browett, J. (1985). The newly industrializing countries and radical theories of development. World Development, 13(7), 789-803. https://doi.org/10.1016/0305-750X(85)90108-1 
Campos, N., \& Kinoshita, Y. (2002). Foreign direct investment as technology transferred: Some panel evidence from the transition economies. The Manchester School, 70(3), 398-419. https://doi.org/10.1111/1467-9957.00309

Chang, R., Kaltani, L., \& Loayza, N. (2009). Openness can be good for growth: The role of policy complementarities. Journal of Development Economics, 90(1), 33-49.

De Mello Jr, L. (1997). Foreign direct investment in developing countries and growth: A selective survey. The Journal of Development Studies, 34(1), 1-34. https://doi.org/10.1080/00220389708422501

Durham, B. (2004). Absorptive capacity and the effects of foreign direct investment and equity foreign portfolio investment on economic growth. European Economic Review, 48(2), 285-306. https://doi.org/10.1016/S0014-2921(02)00264-7

Fry, M. (1993). Foreign Direct Investment in a Macroeconomic Framework: Finance, Efficiency, Incentives, and Distortions. Working Paper 1141. World Bank, International Economics Department, Washington, D.C.

Gohou, G., \& Soumaré, I. (2012). Does foreign direct investment reduce poverty in Africa and are there regional differences? World Development, 40(1), 75-95. https://doi.org/10.1016/j.worlddev.2011.05.014

Hermes, N., \& Lensink, R. (2003). Foreign direct investment, financial development and economic growth. The Journal of Development Studies, 40(1), 142-163. https://doi.org/10.1080/00220380412331293707

Herzer, D., \& Klasen, S. (2008). In search of FDI-led growth in developing countries: The way forward. Economic Modelling, 25(5), 793-810. https://doi.org/10.1016/j.econmod.2007.11.005

Jones, L., \& Manuelli, R. (1995). Growth and the effects of inflation. Journal of Economic Dynamics Control, 19(8), 1405-1428. https://doi.org/10.1016/0165-1889(94)00835-6

Khan, A.R. (2007). Growth, employment and poverty: An analysis of the vital nexus based on some recent UNDP and ILO/SIDA studies. DESA Working Paper, 49. Retrieved from http://www.un.org/esa/desa/papers

Laura, A., Areendam, C., Sebnem, K., \& Sayek, S. (2004). FDI and economic growth: the role of local financial markets. Journal of International Economics 64 (1), 89-112. https://doi.org/10.1016/S0022-1996(03)00081-3

Nair-Reichert, U., \& Weinhold, D. (2001). Causality tests for cross-country panels: a New look at FDI and economic growth in developing countries. Oxford Bulletin of Economics Statistics, 63(2), 153-171. https://doi.org/10.1111/1468-0084.00214

Obadan, M. (2008). Contemporary Issues in Global Trade and Finance and their Implications. Journal of Economic Management, 6 (1).

OECD Publications Centre. (2015). African Economic Outlook 2015: Regional Development and Spatial Inclusion.

Pesaran, M.H., \& Shin, Y. (1996). Cointegration and speed of convergence to equilibrium. Journal of Econometrics, 71(1-2), 117-143.

Sbia, R., Shahbaz, M., \& Hamdi, H. (2014). A contribution of foreign direct investment, clean energy, trade openness, carbon emissions and economic growth to energy demand in UAE. Economic Modelling, 36, 191-197. https://doi.org/10.1016/j.econmod.2013.09.047

Sokhanvar, A. (2019). Does foreign direct investment accelerate tourism and economic growth within Europe? Tourism Management Perspectives, 29, 86-96. https://doi.org/10.1016/j.tmp.2018.10.005 
Solow, R. M. (1956). A contribution to the theory of economic growth. The Quarterly Journal of Economics, 70(1), 65-94. https://doi.org/10.2307/1884513

Su, Y., \& Liu, Z. (2016). The impact of foreign direct investment and human capital on economic growth: Evidence from Chinese cities. China Economic Review, 37, 97-109. https://doi.org/10.1016/j.chieco.2015.12.007

Sunde, T. (2017). Foreign direct investment, exports and economic growth: ADRL and causality analysis for South Africa. Research in International Business Finance, 41, 434-444. https://doi.org/10.1016/j.ribaf.2017.04.035

Svilokos, T., Vojinić, P., \& Šuman Tolić, M. (2019). The role of the financial sector in the process of industrialisation in Central and Eastern European countries. Economic Research-Ekonomska Istraživanja, 32(1), 384-402.

Sylwester, K. (2005). Foreign direct investment, growth and income inequality in less developed countries. International Review of Applied Economics, 19(3), 289-300. https://doi.org/10.1080/02692170500119748

World Bank Data Base. (2018). World Bank Development Indicators. Retrieved from https://data.worldbank.org/

Yamin, M., \& Sinkovics, R. (2009). Infrastructure or foreign direct investment?: An examination of the implications of MNE strategy for economic development. Journal of World Business, 44(2), 144-157. https://doi.org/10.1016/j.jwb.2008.05.004

Zhang, K. H. (2001). How does foreign direct investment affect economic growth in China? Economics of Transition, 9(3), 679-693. https://doi.org/10.1111/1468-0351.00095

The journal is co-financed in the years $2019-2020$ by the Ministry of Science and Higher Education of the Republic of Poland in the framework of ministerial programme "Support for Scientific Journals" (WCN) on the basis of contract no. 238/WCN/2019/1 concluded on 15 August 2019. 


\section{Authors}

The contribution share of authors is equal and amounted to $25 \%$ for each of them.

\section{Michael Appiah}

PhD Student at the School of Finance \& Economics, Jiangsu University, China with research interests in Economic Growth \& Development, Sustainable Growth \& Management etc. He is also the Director of Dorstell Consult Ltd, Ghana.

Correspondence to: Michael Appiah, School of Finance \& Economics, Jiangsu University, China, e-mail: appiahjunior@yahoo.com

ORCID (1) http://orcid.org/0000-0001-9314-4908

\section{Fanglin Li}

Associate Professor and a Doctoral Supervisor at the School of Finance \& Economics, Jiangsu University, China with research interests in Environmental and economic Statistics, Sustainable development assessment and Environment policy and ecological management.

Correspondence to: Prof. Fanglin Li, School of Finance \& Economics, Jiangsu University, China, e-mail:656575905@qq.com

\section{Doreen Idan Frowne}

Student at the Koforidua Technical University in the Faculty of Business and Management Studies. Miss Idan Frowne has been an industrial player with 3 years of working experience as both a management assistant and an administrative secretary.

Correspondence to: Doreen Idan Frowne, Faculty of Business, Koforidua Technical University, Ghana, e-mail: doridan2010@yahoo.com

\section{Daniel Tetteh Donkor}

Bachelor of Commerce (Bcom) from the University of Cape Coast, Ghana. He is currently an Accountant with seven (7) years' experience in accounting \& finance in the Educational sector in Ghana.

Correspondence to: Daniel Tetteh Donkor, School of Business, University of Cape Coast, Ghana, e-mail: kobbytwelve@gmail.com

\section{Acknowledgements and Financial Disclosure}

The authors would like to thank three anonymous reviewers whose comments helped to significantly improve the quality of this publication

\section{Copyright and License}

This article is published under the terms of the Creative Commons Attribution - NoDerivs (CC BY-ND 4.0) License http://creativecommons.org/licenses/by-nd/4.0/ 